\title{
Breastfeeding under the umbrella of support networks: a facilitative strategy
}

\author{
A amamentação sob a égide de redes de apoio: uma estratégia facilitadora \\ La lactancia bajo la égida de redes de apoyo: una estrategia facilitadora
}

\author{
Yamê Regina Alves ${ }^{1}$ (1) \\ Leila Leontina do Couto $^{1}(\mathbb{C})$ \\ Ana Claudia Mateus Barreto ${ }^{1}$ (ID) \\ Jane Baptista Quitete ${ }^{1}$ (1)
}

1. Universidade Federal Fluminense.

Rio das Ostras, RJ, Brasil.
Corresponding author:

Yamê Regina Alves.

E-mail: yamealves@gmail.com

Submitted on 01/21/2019.

Accepted on 09/04/2019.

DOI: 10.1590/2177-9465-EAN-2019-0017

\section{Abstract}

Objectives: To know the aspects related to breastfeeding from the perspective of women in a city in the inland of Rio de Janeiro and to discuss the family support network created as a facilitation strategy for women to breastfeed their children. Methods: A qualitative, descriptive and exploratory research. For data collection, a semi-structured interview script instrument was developed. The focus groups were filmed, and the speeches transcribed in full. Data was divided and grouped into thematic categories. A total of ten volunteer women participated. The reference used was the National Breastfeeding Policy. Results: The following categories emerged from the focus groups: Breastfeeding: facilities and difficulties faced; Prenatal specificities and identification of the support network during breastfeeding. Conclusion and implications for practice: Breastfeeding is an action based on subjectivity, women's experience and among members of the social network. The results point to the need for effective participation of prenatal nurses who promote breastfeeding and the inclusion of the father for better participation in the entire breastfeeding process and family members, where both play a key role in promoting breastfeeding, and continued breastfeeding. Maternal exclusive.

Keywords: Breastfeeding; Women's Health; Social Networking; Social Support; Nursing.

\section{REsUMO}

Objetivos: Conhecer os aspectos relacionados à amamentação sob a ótica de mulheres de uma cidade do interior do Rio de Janeiro e discutir a rede de apoio familiar construída como estratégia facilitadora para a mulher amamentar a criança. Métodos: Pesquisa qualitativa, descritiva e exploratória. Para a coleta de dados, foi elaborado um instrumento tipo roteiro de entrevista semiestruturado. Os grupos focais foram filmados e as falas transcritas na íntegra. Os dados foram fracionados e agrupados em categorias temáticas. Participaram, ao todo, dez mulheres voluntárias. O referencial utilizado foi a Política Nacional de Amamentação. Resultados: Emergiram, dos grupos focais, as categorias "Amamentação: facilidades e dificuldades enfrentadas" "Particularidades do pré-natal" e "Identificação da rede de apoio durante a amamentação". Conclusão e implicações para a prática: A amamentação é uma ação fundamentada na subjetividade, na vivência das mulheres e entre os membros da rede social. Ressalta-se a necessidade da participação efetiva da(o) enfermeira(o) no pré-natal, promovendo o aleitamento materno e a inclusão do pai para melhor participação em todo o processo do aleitamento e dos familiares, onde ambos possuem pape fundamental na promoção e continuidade do aleitamento materno exclusivo.

Palavras-chave: Aleitamento Materno; Saúde da Mulher; Rede Social; Apoio Social; Enfermagem.

\section{RESUmen}

Objetivos: Conocer los aspectos relacionados con la lactancia materna desde la perspectiva de las mujeres de una ciudad del interior de Río de Janeiro y discutir la red de apoyo familiar creada como una estrategia facilitadora para que las mujeres amamanten a sus hijos. Métodos: Investigación cualitativa, descriptiva y exploratoria. Para la recopilación de datos se desarrolló un instrumento de guión de entrevista semiestructurado. Los grupos focales se filmaron y el discurso se transcribió en su totalidad. Los datos se fraccionaron y agruparon en categorías temáticas. Participaron un total de diez mujeres voluntarias. La referencia utilizada fue la Política Nacional de Lactancia Materna. Resultados: Las siguientes categorías surgieron de los grupos focales: Lactancia materna: instalaciones y dificultades enfrentadas; Las peculiaridades prenatales y la identificación de la red de apoyo durante la lactancia. Conclusión e implicaciones para la práctica: La lactancia materna es una acción basada en la subjetividad, la experiencia de las mujeres y entre los miembros de la red social. Los resultados muestran la necesidad de una participación efectiva de las enfermeras prenatales que promueven la lactancia materna y la inclusión del padre para una mejor participación en todo el proceso de lactancia materna y los miembros de la familia, donde ambos juegan un papel fundamenta en la promoción y continuación de la lactancia materna exclusivo materno.

Palabras clave: Lactancia Materna; Salud de la Mujer; Red Social; Apoyo Social; Enfermería 


\section{INTRODUCTION}

The benefits of breastfeeding for the mother-baby binomial are scientifically recognized due to factors such as: its nutritional value; its immune protection; less contamination; protection against obesity and diabetes and a great relevance in the decline of infant morbidity and mortality due to respiratory infections and diarrheal episodes. ${ }^{1}$

Successful breastfeeding is strongly linked to the puerperal support network. This support network directly contributes to meeting women's physical, emotional, social, cultural, intellectual and professional needs. The agents that make up this network are essential for the establishment and maintenance of breastfeeding in a healthy and pleasant way for all involved. ${ }^{2}$

Motivated by economic, political, ideological, family and generational factors, breastfeeding also portrays sociocultural issues that need development in different contexts and in effective physical and emotional conditions. The structuring of the process of breastfeeding takes place in the family context, because this is where many different experiences of women from the same nucleus and from different generations follow one another. ${ }^{3}$

The complexity of the breastfeeding process should not be ignored and each research on this theme points out relevant issues that need to be addressed, such as the influence of social networks on the mother/child binomial. Social networks can be divided into primary and secondary nature. In primary networks, established bonds are defined by kinship, friendship, or neighborhood relationships. Secondary networks can be characterized by relationships with health institutions, education, social assistance and others. ${ }^{4}$

Over the past 30 years, Brazil has participated in and developed various tools aimed at contributing, directly or indirectly, to exclusive breastfeeding up to six months of life of newborns and infants. However, despite all the scientific evidence and efforts of various national and international bodies, which prove the superiority of breastfeeding over other ways of feeding young children, the prevalence of breastfeeding in Brazil, especially that of exclusive breastfeeding, is well below the recommended level and the health professional plays a fundamental role in reversing this situation. ${ }^{5}$

In considering the need to encourage breastfeeding, foster mother/child relationships and the development of health education programs, the Ministry of Health published Ordinance GM/MS 1016 in August 1993. This ordinance was revoked with the publication of the Ordinance 2,068, on October $21^{\text {st }}, 2016$, which instituted guidelines for the organization of comprehensive and humanized care for women and the newborn in the rooming-in. This new ordinance brings in its content the importance of promoting and protecting breastfeeding on demand, supporting the postpartum woman in overcoming possible difficulties according to her specific needs and respecting her individual characteristics. ${ }^{6}$
In order to strengthen the previous recommendations, Law No. 13,435, which instituted August as the Breastfeeding Month (Golden August), was approved on April 12, 2017. The objective was to intensify inter-sectoral actions to raise awareness and clarify the importance of breastfeeding. ${ }^{7}$

Action is needed to ensure, through legal protection, the right to breastfeeding. Likewise, it is essential to develop actions aimed at promoting breastfeeding, mobilizing society to fulfill these rights. In addition, it is imperative that breastfeeding women be given full support and attention to their needs, especially in health services. ${ }^{8}$

The activities in health education for couples who experience the pregnancy-puerperal period are extremely necessary, as they need to share knowledge and reflections on the changes experienced, providing a preparation from the body and emotional point of view through exchange of experiences. ${ }^{9}$ The lack of these activities during prenatal care can affect the lives of these women regarding the success of breastfeeding. During the prenatal period, the woman will build for herself reasons that will help her in making decisions about experiencing childbirth in a positive way, with fewer complications during the postpartum period and successful breastfeeding of her child. ${ }^{10}$

Given the above, the objectives of this study were outlined to know the aspects related to breastfeeding from the perspective of women in a city in the interior of Rio de Janeiro and discuss the family support network built as a facilitating strategy for women to breastfeed the child.

The theoretical foundation of this study was based on the National Breastfeeding Policy.

\section{METHOD}

This is a qualitative, descriptive and exploratory research. This type of research intends to answer very particular questions, since the problems involved are at a level of reality that cannot be quantified. A qualitative research works with the universe of meanings, motives, aspirations, beliefs and values of each individual. ${ }^{11}$

Data collection took place in two municipalities of the coastal lowland of the State of Rio de Janeiro between January and April 2018. The study had four meetings, counting twenty-nine women in all, where ten participating women effectively met the inclusion and exclusion criteria. The inclusion criteria were women over 18 years of age, regardless of parity, who have had at least one fullterm child without pathologies or syndromes. This child should be at least one month old and a maximum of two years old by the date of data collection. In addition, there should have been at least six prenatal consultations by the Unified Health System (Sistema Único de Saúde, SUS). The exclusion criteria were women who were emotionally unstructured due to the birth of their child and some difficulty participating in data collection for family or personal problems. 
For data collection, a semi-structured interview script instrument was developed. The first part of the script raised data that enabled the characterization of the participants and the second part of the instrument brought a thematic script with open questions covering the following themes: breastfeeding; hygiene; skin care; care with the umbilical stump; sleep and rest; abdominal cramps and others that came up.

The focus group lasted approximately ninety minutes. The pedagogical approach used was the conversation wheel, as it is a method that enabled a dynamic and productive communication, being a rich instrument to be used as a methodological practice that stimulates the approach between the subjects in the pedagogical routine. ${ }^{12}$

Before starting data collection, the participants were informed about the research and signed two copies of the Free Informed Consent Form (FICF), in compliance with Resolution 466/2012 of the National Health Council. ${ }^{13}$ To ensure the anonymity of the participants, they were named with flowers names both in the data collection instrument and in the transcription of audios and footage.

The focus group was filmed and later the lines were transcribed in full. The data collected in the first part of the instrument underwent profile analysis and characterization of the participants. Data derived from speech transcription was fractionated into incidents and subsequently grouped by thematic categories, according to Bardin. ${ }^{14}$

This research project was approved by the Ethics and Research Committee (Comitê de Ética e Pesquisa, CEP) of the Fluminense Federal University, on November $29^{\text {th }}, 2017$, under the following opinion number: $2,406,321$ and CAAE: 76610517.1.0000.5243.

It is emphasized that this article derives from a larger study with the following title: "The woman, prenatal care and care of the real baby."

\section{RESULTS}

It was found that the age group for the ten participating women was between twenty and thirty-seven years old, with a mean of 32.4 years old. Among the participants, the level of education found was three with incomplete elementary school, six with complete high school and one with complete higher education. All participants had their last pregnancy prenatal care through the SUS, three with seven consultations, three with eight, two with ten and two with eleven consultations, with a mean of 8.7 prenatal consultations.

Regarding breastfeeding, the data found were as follows: four participants reported exclusive breastfeeding until the sixth month of the baby; two maintained mixed breastfeeding, which consists of breastfeeding plus the supplement of formula until the fourth month, with the introduction of food from that time; three sustained mixed breastfeeding until the sixth month and one maintained the use of formulas only, i.e., without breastfeeding at any time.
Among the participants, there were six primiparous and four multiparous, the latter bringing the most comparisons of experiences within pregnancy, prenatal, delivery and postpartum. Of the multiparous women, three had two pregnancies and two deliveries and one participant had three pregnancies and three deliveries.

Regarding previous breastfeeding experiences, among the participants, one reported exclusive breastfeeding with her first child; two had mixed breastfeeding and one reported formula use. None of the ten participants reported abortion.

Regarding the support network of these women, 90\% reported obtaining the family support network, of which three obtained exclusive support from their mothers and one from their mother-in-law only; one from her aunt; three, concomitant support from mothers, partner, aunt and mother-in-law; one from the neighbor and one had no support at all. It is noteworthy that the participant who reported not having a support network during maternity was the same who did not breastfeed since birth. All reported that even with family support network, they had difficulties in the postpartum period, and these difficulties are very wide, such as tiredness, feeling of unpreparedness, loneliness, among others. An important element highlighted by the participants was the lack of professional support network during prenatal and postpartum periods. It should be noted that the women interviewed recommended that prenatal care be a moment of welcoming, empathic listening and preparation for the future.

As a result of the focus group, three thematic categories emerged: "Breast-feeding: facilities and difficulties faced"; Prenatal Particularities" and "Identification of the support network during breastfeeding".

\section{I - Breastfeeding: facilities and difficulties faced}

Participants reported feelings such as tranquility and satisfaction related to the act of breastfeeding their children. Being able to breastfeed with peace denotes pride for some of the women interviewed.

Women had a clear perception of the value of breastfeeding, recognizing that the act of breastfeeding guaranteed them a pleasurable practice. Moreover, in their speeches, they described the values linked to well-being, nutrition and affection.

[...] my oldest daughter, who is thirteen years old, I breastfed until the age of eight, exclusively ... for me, was very good and pleasant [...]. (Iris)

[...] my first breastfeeding was very quiet, and I breastfed my first daughter until six months exclusively [...] I breastfed until two years old [...]. (Jasmine)

[...] when you have milk, it must be very quiet, it must be that good thing [...] because you must be well, if not, it doesn't happen and, in this son, it was all very hectic [...]. (Lily) 
The participants Iris and Jasmine presented the most comparisons between the lived experiences, highlighting the particularities of each moment between mothers, children and family, demonstrating that, in each pregnancy, breastfeeding is unique.

Some women reported that they had difficulties and even complications during the breastfeeding process, such as initial pain, nipple injury, and difficulty catching the baby. These situations are not discussed in the prenatal period with the woman, thus hindering the mother's adaptation process to this new activity, interfering with the quality and time of breastfeeding the child.

[...] breastfeeding hurts too much and takes too long to reach the milk, nobody tells us about it [...]. (Amaryllis)

[...] it hurts a lot when the baby is breastfeeding, he would suckle, suckle, suckle and cry all night [...]. (Tulip)

[...] my breast hurt so much that blood came out [...]. (Petunia)

\section{II - Prenatal Features}

Participants reported difficulties in performing their prenatal care through the Unified Health System, confirming the gaps regarding the difficulties of making appointments and performing exams during prenatal care. It is noteworthy that the participants in this study had more prenatal visits than recommended by the Ministry of Health and even the new recommendation of the World Health Organization.

\section{[...] I did not feel dear in prenatal care, they did not look at my difficulties [...]. (Amaryllis)}

[...] we mothers apparently don't even know what prenatal is for. Each doctor does it in a way [...]. (Petunia)

[...] at SUS, nothing is good, is it? They only measured the belly and listened to the heart [...]. (Hortence)

The women alluded that some guidelines should have been addressed during prenatal consultations, such as guidance on child care at home, questions about pregnancy, issues related to breastfeeding that were not satisfactorily addressed during prenatal care and the importance of construction of a dialogue and bond with the health professional. It is noteworthy that this last statement was pointed out by all women during the group interview.

[...] it would be the woman's means of information... where she was free to ask, not only about the doctor talking [...]. (Azalea)

[...] prenatal care is very focused on the care of the pregnant woman and the baby being raised there and only [...]. (Iris)
[...] It's just the moment of pregnancy. Because the after is not in prenatal, the after when the baby is born... this could all be added in prenatal [...]. (Lavender)

\section{III - Identification of support network during breastfeeding}

The participants mentioned, in their reports, the participation of the primary support network, which was composed of family members and individuals who lived close to the mother-woman, pointing out positive and negative issues in their experiences when breastfeeding and caring for the baby.

In this study, most women reported that they had a support network of close women in caring for the newborn.

[...] I had my father and mother, when I was three months old, I separated, so I had to turn around, I had this difficulty with my partner [...]. (Azalea)

[...] I had my mother-in-law for the first two weeks and then it was me, my husband and God [...]. (Iris)

[...] I had my mother and my aunt. My mate gives me more work than the baby. If it wasn't for my mother, I would be desperate [...]. (Lavender)

The women identified and reported the lack of support from their partners, who were not available to help, directly interfering with the quality of breastfeeding.

[...] I had no partner; I had no support. So, I think this may have been the reason why you cannot breastfeed because you must be well, if not, it does not happen [...]. (Lily)

[...] my husband didn't help at all, just slept. He lived tired. The child cried and when I told him to hold it, he pretended to be asleep and everything ... was dead! Is woman the fragile sex? [...]. (Azalea)

[...] my partner doesn't even help to make dinner [...]. (Amaryllis)

The importance of the welcoming and support of the partner is evidenced, thus creating a new family model for all involved and giving rise to the mother-father-baby trinomial.

Some women reported a feeling of loneliness related to the responsibility of caring for a care-dependent child. They reported having experienced motherhood in isolation, despite having some support network, thus showing how each woman experiences the profound transformations in the postpartum period and how much this period may imply loneliness for some women.

[...] you have no basis and you must learn that in practice, many things, you ask yourself: "How am I going to do this?" [...]. (Jasmine) 
[...] most mothers go through a situation of feeling lonely, thinking that they are too heavy, wondering if they will realize why this stress of not sleeping well... of having a being that totally depends from you [...]. (Azalea)

[...] but there is loneliness, sometimes it seems that you are the only one who can do that and that you are alone [...]. (Tulip)

\section{DISCUSSION}

In order to contribute to the formulation and agreement of the National Policy for the Promotion, Protection and Support of Breastfeeding in Brazil, the document was published by the Ministry of Health in 2017: Bases for Discussion of the National Policy for the Promotion, Protection and Support of Breastfeeding, reflecting on the need to strengthen the various actions to encourage breastfeeding developed in the country since the 1980s. ${ }^{7}$

Despite investment in breastfeeding promotion, promotion and support policies, In low- and middle-income countries, there is a low prevalence of exclusive breastfeeding. The percentage of $37 \%$ in children under six months is like that found in assessing the trend of breastfeeding indicators in Brazil over the past 30 years, even though scientific evidence has shown the superiority of breastfeeding over other forms of breastfeeding. Despite the efforts of various national and international organizations, the results are falling short of the recommended. ${ }^{5,15}$

In order to ensure, through legal protection, the right to breastfeeding, it is essential to develop actions aimed at promoting breastfeeding, mobilizing society and ensuring greater investment in this type of health care. ${ }^{7}$

The high age range correlates favorably with the provision of guidance received. While low education is appropriate to risk factors for the development of newborns, correlations not found in this study, where the age and study are high, however, participants reported that there are few guidelines regarding breastfeeding during prenatal care, making them ineffective. ${ }^{16,17}$

The realization of the benefits of breastfeeding is vital and indisputable. According to the authors, each woman experiences this process in a unique way with her principles regarding breastfeeding. ${ }^{18}$ From this point of view, we can highlight the previous experiences of some women regarding breastfeeding, which can be elements of encouragement and affirmation in the act of breastfeeding or giving up this practice, if they do not receive attention and encouragement.

The difficulty in adapting between the baby and the mother can negatively contribute to the process of breastfeeding due to excessive tiredness, insecurity and maternal stress, contributing to weaning and compromising child development. ${ }^{19}$

It is clear from the testimonies that, even if the woman experiences pain and discomfort, she chooses to breastfeed. This stance is highlighted by two motivations: first, the prioritization of breastfeeding regardless of any adversity the woman is experiencing, and the second motivation is the value attributed to motherhood, i.e., maternal love. ${ }^{20}$

In addition, maternal confidence or lack of breastfeeding can be considered an important variable not only for initiating breastfeeding but also for maintaining it exclusively. ${ }^{21}$

Regarding the primary support network, the highlight is the accumulation of women's roles today, where there is some difficulty in adapting to the new reality and understanding of the roles to be played in breastfeeding. Although the inclusion of the family in this practice is reinforced, in most cases, the absence of the father figure in prenatal consultations and newborn care is identified. This presence, in most cases, is little encouraged and much less considered as a relevant element in the primary support network.

By confirming the relevance of this presence, we highlight the change in the behavior of parents, with their insertion in the educational activities of prenatal and postpartum, fundamental behavior in the care of the baby, the wife and the act of breastfeeding. ${ }^{22}$ Nurses are also directly responsible for the inclusion of the father, stimulating and guiding the care of his child, as well as helping women to overcome possible obstacles in the breastfeeding process. Thus, the inclusion of the father allows for the visualization of how he sees and perceives his active participation in the process of nurturing the baby, as well as his participation as an active member of the support network.

Reinforcing this attitude of encouraging the father's participation in the newborn child health process, the Integrated National Policy for Early Childhood was created, changing the extension of paternity leave from five to twenty days. This was a way to ensure the participation of the father in the first moments of the children's life, because the paternal presence becomes a right of the child and enables the division between men and women in childcare tasks. ${ }^{23}$

Despite the existence of the policy allowing for twenty-day paternity leave, it is noteworthy that this is not a guarantee of your participation in childcare, nor does it cater to those parents who have no employment or informal employment. This characterizes a cultural, social and political issue regarding early childcare.

Nursing is characterized as the secondary support network for women, most involved during the breastfeeding process, being an important support for nursing mothers when difficulties arise. ${ }^{4}$ It is noteworthy that the presence of the nurse in the breastfeeding process should not be relevant only in the difficulties, as pointed out by some authors, but a professional who follows the whole process, with a participant presence in the exchange of experiences, health information and motivations to face this new breastfeeding experience.

One of the most relevant characteristics in prenatal care is the bond and the reception of pregnant women with health professionals, due to the body of knowledge that the professional has with the association of clinical knowledge, scientific evidence, to identify and address particularities of each woman. The established and strengthened bond allows us to understand the 
needs, abilities and limitations of women in understanding the gestational process and birth. The performance of nurses should lead to well-being and safety. ${ }^{24}$

Interventions directed at pregnant and postpartum women become fundamental health promotion strategies. The goal, in this case, of providing a more balanced experience of all emotions and phenomena that occur during the pregnancypuerperal period, keeps the respect and monitoring of women in their decisions. ${ }^{25}$

In a quantitative study related to educational intervention, it was found that correcting or minimizing negative beliefs and consolidating positive beliefs in maternal self-efficacy to breastfeed correspond positively to the ability to breastfeed. ${ }^{21}$

It is important to disseminate information to ensure legal protection and the right to breastfeeding, just as it is essential to strengthen actions aimed at promoting breastfeeding, encouraging society to exercise these rights. It is essential to ensure breastfeeding support and full attention to their needs, making it essential to establish an inter-sectoral agenda that conceives the actions necessary for breastfeeding practice. ${ }^{7}$

The participants in this study could not identify nursing professionals as a support network for breastfeeding in the postnatal period. Regarding prenatal care, the few guidelines received on the subject were highlighted. Its possible difficulties and especially its benefits were not questioned during follow-up. Some women even correlated this lack of information to the fact that their prenatal care was followed in the Unified Health System and had a negative effect on their quality.

In contrast, the author ${ }^{18} \mathrm{emphasize}$ that the health network is configured to support breastfeeding and should be the object of attention and dedication of health professionals who work with women who breastfeed, aiming to succeed in the breastfeeding process. It is mandatory to reinforce these precepts, within the criteria of guaranteeing effective prenatal care, to ensure educational practices, addressing the encouragement of breastfeeding. ${ }^{26}$

The average number of consultations found in these studies was higher than the minimum number recommended by the Ministry of Health of six consultations and the number recommended by the World Health Organization of eight consultations per pregnancy. ${ }^{27,28} \mathrm{However}$, there is no consensus on the optimal number of consultations, as it is proven that a small number of consultations, performed in a qualified manner, can be as efficient as performing them in greater numbers. ${ }^{29}$

The process of health education is an indispensable attribute to the work of Nursing, being relevant to analyze and recognize in which model of health education the practices of nurses are based; the adopted methodologies, the approached contents and the protagonist actions being present in the orientation of the educative process. Thus, these factors would lead to the lack of professional practice, which may lead to a lack of professional training, generating a reduced quality standard. ${ }^{29,30}$
The primary support network of these women was composed mostly of women, such as their mothers, grandparents, aunt and neighbors, where the breastfeeding woman recognizes female figures, who had already experienced, directly or indirectly, motherhood, reinforcing the importance of the exchange of information experiences.

The psychological and emotional moment that each woman experienced during the puerperal period should also be emphasized. Parturition of a newborn results in a change of roles, providing a restructuring of the woman's identity where the daughter becomes a mother. ${ }^{31} \mathrm{~A}$ moment of intense emotional changes, highlighting the importance of the family support network, both for direct care of the newborn and care for the postpartum woman, who experiences moments of loneliness and delivery to the new family member, as pointed out in the reports.

Fatigue from the practice of breastfeeding is indicated as the cause of early weaning, requiring family support, friends and professionals, so that women experience exclusive breastfeeding in a healthy way, thus easing the burden of women. ${ }^{32}$

The family, as a network, has the potential to provide support to its members. She acts by encouraging the mother-baby binomial, their intimacy, communication and knowledge. The family, therefore, can be recognized as the mother-child social support network, breastfeeding promotion and care network. ${ }^{33}$

\section{CONCLUSION AND IMPLICATIONS FOR THE PRACTICE}

Breastfeeding is neither instinctive nor automatic, but an action that is based on the subjectivity and experience of women, being conditioned by the relationships established with the members of their social network.

The family plays a fundamental role in promoting and continuing the practice of exclusive breastfeeding due to their accumulated experiences before motherhood.

In this study, the importance of the family was highlighted, and its action was characterized as a care strategy in the maternal and child health education line for Nursing, and it can be a very useful tool to chart new paths in obstetric and childcare.

In the family routine, a greater opportunity for encouraging exclusive breastfeeding until the sixth month was identified with the identification of problems arising from the act of caring.

The inclusion of the father since prenatal as a key role in the support network is indispensable for the success of breastfeeding, which will come from active changes of nursing professionals, early starting continuous actions of education during prenatal, to strengthen breastfeeding, strengthening and preparing the family context for the arrival of the newborn.

The primordial act of preparation and strengthening of this context was not evidenced in this study; however, it is evident that the actions may be decisive in the success of policies to encourage exclusive breastfeeding. 
The need for reorganization of health services is also emphasized, with the support of the State and society, in order to ensure comprehensive, integrated and integrative care.

This study presented, as a limitation, the demographic coverage, as it was carried out in the inland of Rio de Janeiro, in two primary care units. However, it was possible to identify the behavior of these women facing breastfeeding, their doubts and questions, which agreed with what the literature presents. It is suggested that the study may be applied in other regions to compare aspects of breastfeeding and the need for support network in different regions.

\section{REFERENCES}

1. Victora CG, Bahl R, Barros AJD, França GV, Horton S, Krasevec J, et al. Breastfeeding in the 21st century: epidemiology, mechanisms, and lifelong effect. Lancet [Internet]. 2016 jan; [cited 2018 apr 10]; 387(10017):475-89. Available from: http://doi.org/10.1016/S01406736(15)01024-7

2. Moreira LA, Cruz NV, Linhares FMP, Guedes TG, Martins FDP, Pontes $\mathrm{CM}$. Support to woman/nourisherin the advertising pieces of the World Breastfeeding Week. Rev Bras Enferm [Internet]. 2017 feb; [cited 2018 apr 10]; 70(1):61-70. Available from: http://dx.doi.org/10.1590/00347167-2016-0376

3. Moreira MA, Ribeiro PS, Ramos JSBM, Dias MBL, Castro JO. Social representations of migrant women of the same family and of different generations on breastfeeding. Rev Enferm UFSM [Internet]. 2017 oct/ dec; [cited 2018 apr 11]; 7(4):669-84. Available from: http://dx.doi. org/10.5902/2179769226544

4. Souza MHN, Nespoli A, Zeitoune RCG. Influence of the social network on the breastfeeding process: a phenomenological study. Esc Anna Nery [Internet]. 2016 nov; [cited 2018 apr 11]; 20(4):e20160107. Available from: http://www.scielo.br/scielo.php?pid=S1414$81452016000400224 \&$ script=sci_arttext\&tIng=en

5. Ministério da Saúde (BR). Secretaria de Atenção à Saúde. Departamento de Atenção Básica. Saúde da criança: aleitamento materno e alimentação complementar [Internet]. Brasília (DF): Ministério da Saúde; 2015; [cited 2018 aug 10]. Available from: http://bvsms.saude.gov.br/ bvs/publicacoes/saude_crianca_aleitamento_materno_cab23.pdf

6. Ministério da Saúde (BR). Gabinete do Ministro. Portaria n. 2.068, de 21 de outubro de 2016. Institui diretrizes para a organização da atenção integral e humanizada à mulher e ao recém-nascido no Alojamento Conjunto [Internet]. Brasília (DF): Ministério da Saúde; 2016; [cited 2018 aug 10]. Available from: http://bvsms.saude.gov.br/bvs/saudelegis/ gm/2016/prt2068_21_10_2016.htm

7. Lei n. 13.435 de 12 de abril de 2017 (BR). Institui o mês de agosto como o Mês do Aleitamento Materno. Diário Oficial da União [Internet], Brasília (DF), 2017 apr 12: Seção 1; [cited 2018 aug 12]. Available from: http://www.in.gov.br/materia/-/asset_publisher/Kujrw0TZC2Mb/ content/id/20164085/do1-2017-04-13-lei-n-13-435-de-12-de-abrilde-2017-20164039

8. Ministério da Saúde (BR). Secretaria de Atenção à Saúde. Departamento de Ações Programáticas Estratégicas. Bases para a discussão da Política Nacional de Promoção, Proteção e Apoio ao Aleitamento Materno [Internet]. Brasília (DF): Ministério da Saúde;2017; [cited 2018 nov 05]. Available from: http://bvsms.saude.gov.br/bvs/publicacoes/ bases_discussao_politica_aleitamento_materno.pdf

9. Guerreiro E, Rodrigues DP, Queiroz ABA, Ferreira MA. Health education in pregnancy and postpartum: meanings attributed by puerperal women Rev Bras Enferm [Internet]. 2014 feb; [cited 2018 nov 05]; 67(1):13-21. Available from: $h$ ttp://dx.doi.org/10.5935/0034-7167.20140001
10. Barbosa LN, Santos NC, Moraes MAM, Rizzardi SD, Corrêa EC. Prevalence of educational practices about exclusive breastfeeding (EBF) in Cuiabá - MT. Esc Anna Nery [Internet]. 2015 jan/mar; [cited 2018 nov 05]; 19(1):147-53. Available from: http://www.scielo.br/pdf/ean/v19n1/ en_1414-8145-ean-19-01-0147.pdf

11. Minayo MCS, Deslandes SF, Cruz Neto O, Gomes R. Pesquisa social: teoria, método e criatividade. 34a ed. Petrópolis: Vozes; 2015.

12. Melo MCH, Cruz GC. Roda de conversa: uma proposta metodológica para a construção de um espaço de diálogo no ensino médio. Imagens da Educação [Internet]. 2014; [cited 2018 nov 26]; 4(2):31-9. Available from: http://dx.doi.org/10.4025/imagenseduc.v4i2.22222

13. Ministério da Saúde (BR). Conselho Nacional de Saúde. Resolução n. 466, de 12 de dezembro de 2012. Aprova as Diretrizes e Normas Regulamentadoras de pesquisa envolvendo seres humanos [Internet] Brasília (DF): Ministério da Saúde; 2012; [cited 2018 nov 26] Available from: http://bvsms.saude.gov.br/bvs/saudelegis/cns/2013/ res0466_12 12 2012.html

14. Bardin L. Análise de Conteúdo. São Paulo: Edições 70; 2011.

15. Boccolini C, Boccolini PM, Monteiro F, Venâncio S, Giugliani E. Breastfeeding indicators trends in Brazil for three decades. Rev Saúde Pública [Internet]. $2017 \mathrm{dec}$; [cited 2018 nov 26]; 51:108. Available from: http://dx.doi.org/10.11606/s1518-8787.2017051000029

16. Tomasi E, Fernandes PAA, Fischer T, Siqueira FCV, Silveira DS, Thumé $\mathrm{E}$, et al. Quality of prenatal services in primary healthcare in Brazil indicators and social inequalities. Cad Saúde Pública [Internet]. 2017 apr; [cited 2018 nov 27]; 33(3):e00195815. Available from: http://dx.doi. org/10.1590/0102-311x00195815

17. Sassá AH, Higarashi IH, Bercini LO, Arruda DC, Marcon SS. At-risk infants: monitoring children's growth in the first year of lif. Acta Paul Enferm [Internet]. 2011; [cited 2018 aug 10]; 24(4):541-9. Available from http://www.scielo.br/pdf/ape/v24n4/a15v24n4.pdf

18. Alves VH, Padoin SMM, Rodrigues DP, Silva LA, Branco MBLR, Marchiori GRS. Clinical management of breastfeeding: axiological value from women's perspective. Esc Anna Nery [Internet]. 2016 oct dec; [cited 2018 nov 26]; 20(4):e20160100. Available from: http://www scielo.br/pdf/ean/v20n4/en_1414-8145-ean-20-04-20160100.pdf

19. Carreiro JA, Francisco AA, Abrão ACFV, Marcacine KO, Abuchaim ESV, Coca KP. Breastfeeding difficulties: analysis of a service specialized in breastfeeding. Acta Paul Enferm [Internet]. 2018 jul; [cited 2018 nov 27]; 31(4):430-8. Available from: http://dx.doi.org/10.1590/19820194201800060

20. Lima SP, Santos EKA, Erdmann AL, Souza AIJ. Unveiling the lived experience meaning of being a woman breastfeeding with puerperal complications. Texto Contexto - Enferm [Internet]. 2018 mar; [cited 2018 nov 28];27(1):e0880016. Available from: http://dx.doi.org/10.1590/010407072018000880016

21. Javorski M, Rodrigues AJ, Dodt RCM, Almeida PC, Leal LP, Ximenes LB. Effects of an educational technology on self-efficacy for breastfeeding and practice of exclusive breastfeeding. Rev Esc Enferm USP [Internet] 2018 jun; [cited 2018 nov 28]; 52:e03329. Available from: http://dx.doi. org/10.1590/S1980-220X2017031803329

22. Lima JP, Cazola LHO, Pícoli RP. Involvement of fathers in the breastfeeding process. Cogitare Enferm [Internet]. 2017 jan; [cited 2018 nov 28]; 22(1):1-7. Available from: http://dx.doi.org/10.5380/ ce.v22i1.47846

23. Ministério da Saúde (BR). Universidade Aberta do SUS (UNA-SUS) Secretaria de Gestão do Trabalho e da Educação na Saúde, Fundação Oswaldo Cruz. Pré-natal do parceiro incentiva homens a cuidarem da saúde [Internet]. Brasília (DF): UNA-SUS; 2014; [cited 2018 nov 28] Available from: https://www.unasus.gov.br/noticia/pre-natal-do-parceiroincentiva-homens-cuidarem-da-saude

24. Quadros JS, Reis TLR, Colomé JS. Obstetrical nursing and health education: contributions to the experience of process of parturition. Rev RENE [Internet]. 2016 may; [cited 2018 nov 29]; 17(4):451-8. Available from: http://dx.doi.org/10.15253/2175-6783.2016000400003 
25. Cunha ACB, Santos C, Gonçalves RM. Conceptions about motherhood childbirth and breastfeeding in group of pregnancies. Arq Bras Psicol [Internet]. 2012 apr; [cited 2018 nov 29]; 64(1):139-55. Available from http://pepsic.bvsalud.org/scielo.php?script=sci_arttext\&pid=S1809$52672012000100011 \& \mathrm{lng}=\mathrm{pt \& n}$ rm=iso\&tlng=pt

26. Ministério da Saúde (BR). Secretaria de Atenção à Saúde. Departamento de Atenção Básica. Atenção ao pré-natal de baixo risco [Internet]. Brasília (DF): Ministério da Saúde; 2012; [cited 2018 aug 10]. Available from: http://bvsms.saude.gov.br/bvs/publicacoes/cadernos_atencao_basica_32_prenatal.pdf

27. Ministério da Saúde (BR). Secretaria de Atenção à Saúde. Departamento de Ações Programáticas Estratégicas. Pré-natal e puerpério atenção qualificada e humanizada [Internet]. Brasília (DF): Ministério da Saúde; 2006; [cited 2018 nov 25]. Available from: http://bvsms.saude. gov.br/bvs/publicacoes/manual_pre_natal_puerperio_3ed.pdf

28. Organização Mundial de Saúde (OMS). Recomendações da OMS sobre cuidados pré-natais para uma experiência positiva na gravidez [Internet]. Genebra: OMS; 2016; [cited 2018 dec 05]; 1-10. Available from: https://apps.who.int/iris/bitstream/handle/10665/250800/WHO RHR-16.12-por.pdf;jsessionid=A5B308DC0005C40A86DDB4326E9 $187 F 5$ ?sequence $=2$
29. Nunes JT, Gomes KRO, Rodrigues MTP, Mascarenhas MDM. Quality of prenatal care in Brazil: review of published papers from 2005 to 2015. Cad Saúde Colet [Internet]. 2016 jun; [cited 2018 dec 05];24(2):252-61. Available from: http://dx.doi.org/10.1590/1414-462X201600020171

30. Cassiano NA, Holanda CSM, Costa RKS, Morais FRR, Maranhão TMO. Nursing care to woman in immediate puerperium: a narrative description. J Res Fundam Care Online [Internet]. 2015 jan/mar [cited 2018 dec 05]; 7(1):2061-71. Available from: http://dx.doi. org/10.9789/2175-5361.2015.v7i1.2061-2071

31. Andrade CJ, Baccelli MS, Benincasa M. The mother-baby bond in the puerperium: a winnicottian analysis. Vínculo [Internet]. 2017; [cited 2018 dec 07]; 14(1)1-13. Available from: http://pepsic.bvsalud.org/scielo. php?script=sci_arttext\&pid=S1806-24902017000100004

32. Rocha GP, Oliveira MCF, Ávila LBB, Longo GZ, Cotta RMM, Araújo RMA. Conditioning factors for exclusive breastfeeding from the mother's perspective. Cad Saúde Pública [Internet]. 2018; [cited 2018 nov 22]; 34(6):e00045217. Available from: http://dx.doi.org/10.1590/0102$311 \times 00045217$

33. Lima IMSO, Leão TM, Alcântara MAR. Right to breastfeeding, right to health and family: the legal protection network in Brazil. Rev Direito Sanit [Internet]. 2014 feb; [cited 2018 nov 22]; 14(3):66-90. Available from: http://dx.doi.org/10.11606/issn.2316-9044.v14i3p66-90 